\title{
English in Korean Advertising: An Exploratory Study
}

\author{
John P. Holmquist ${ }^{1} \&$ B. Andrew Cudmore ${ }^{1}$ \\ ${ }^{1}$ Florida Institute of Technology, Melbourne, FL, USA \\ Correspondence: John P. Holmquist, 105 Stone Street, Cocoa, FL, 32922, USA. Tel: 1-321-452-9701. E-mail: \\ john.holmquist@gmail.com
}

Received: March 16, 2013

Accepted: April 5, 2013 Online Published: April 16, 2013

doi:10.5539/ijms.v5n3p94

URL: http://dx.doi.org/10.5539/ijms.v5n3p94

\begin{abstract}
The use of English language names, titles, and catchphrases are often presented in advertisements that do not necessarily target English-reading clientele in South Korea. This paper explores the functionality and characteristics of English text found in Korean promotion. This was a multistep exploratory study of the use and acceptance of English in Korean advertisements. First, various Korean media sources were scrutinized to determine the percentage of promotions that exhibited English and how it was utilized. Second, a survey regarding the acceptance and perception of English in these promotions by the Korean consumer was conducted. Third, a vocabulary test of the most common English descriptive words utilized in Korean magazine advertisements was given to Korean business students. It was determined that $59.5 \%$ of the advertisements contained English words. The survey revealed evidence that English in Korean promotions is well received with the majority agreeing that the English language is novel or exoticness. The twenty most commonly found English words presented in Korean magazine advertisements were only understood $58.5 \%$ of the time by the business college students surveyed. This study shows that international and native Korean firms are having success in the Korean market by using marketing that integrates English has a means to show style and appeal to the Korean customers. The findings suggest that the Korean consumer finds the use of English to be appealing regardless of their comprehension of the language itself.
\end{abstract}

Keywords: English, marketing, advertisements, perceptions, recall, Korean

\section{Introduction}

\subsection{Introduction of the Problem}

The use of a foreign language to promote a product is not uncommon in certain industries (e.g., perfumes). A review of the recent literature reveals that foreign languages are being used in advertisements across the globe, from Europe (Gerritsen, Korzilius, VanMeurs, \& Gijsbers, 2000) to Taiwan (Wang \& Chen, 2004), especially the language of Americanized English in locations wherein English is not the native or primary tongue. By some accounts, English has become the "second language" of the world for the purposes of business and travel (Crystal, 1997). So the question remains as to the rationale for the use of English in foreign promotions. Logically its use would suggest some form of functionality. That is, English could be used to promote information (e.g., providing clarity or succinctness), or a positioning based on the meaning of the words (e.g., implying "state of the art"), the look/style of the words, or some phonetic (e.g., "exotic" sounding) aspect of the words. The extant literature is relatively silent on the functionality of English in foreign promotions. In particular, no rationale is found in the literature for the popularity of English in promotions in localized, non-English speaking markets, such as South Korea. In fact, given the extent of the use of English in the presence of strong country of origin effects (Han 1990), South Korea maybe a conservative test of the use of English in promotions (Schooler,1965; Usunier, 2006).

This paper is organized in the following manner. First, a summary of why English may be commonly used is provided. Secondly, the methodologies used to assess these potential reasons are described. Three different analyses were employed in this paper: an exploratory study of Korean advertisements to determine the percentage of which featured English and how it was utilized, and then a further analysis of the twenty most commonly found English descriptive words as gleaned from the advertisements review. This analysis included the surveying of native Koreans to test their actual comprehension of the English words, and then questioning their views on why English was used in their native media. 


\subsection{Recall and Comprehension}

A simple metric of the transference of information is recall. One study of Hispanics revealed that recall is significantly better if the message is presented in their own language, instead of, even with bilingual Hispanics (Nicholls \&Roslow, 1996). This suggests the use of a foreign language in promotions would be a disadvantage to

recall. This study utilized thirty second commercials in an experimental design where these ads were completely in English or Spanish, however our focus is on the intermittent use of English imbedded within a foreign language promotion.

Once the information is recalled there still is the matter of comprehension. Interestingly, research by De Mooij (1994) showed that there is a misunderstanding of the level of consumer proficiency of the English language worldwide. De Mooij points out that those marketers have wrongly assumed that the average international consumer has a basic working knowledge of English, when in actuality, they do not. This fallacy presented by De Mooij, coupled with the nearly ubiquitous use of English in business and travel, and could explain the common use of English in international advertising.

\subsection{Country of Origin Effects}

Rules of origin distinguish between preferential and non-preferential treatment of goods. Similarly, country of origin effects distinguishes between a preferential and non-preferential treatment of foreign goods (Han 1990). This effect represents either the positive or negative connotations of quality and value to which a product is ascribed based on the country in which it was designed or manufactured (Han, 1990; Parameswaran \& Pisharodi, 1994). In fact, consumers often perceive products as superior to others based on country of origin alone (Darling \&Wood, 1990; Han, 1990; Cordell, 1992; Tse \& Gorn, 1993). Specifically, this means a preference for domestic goods and services whether they are deliberate decisions or subconscious influences (Lubatkin, Calori, Very, \& Veiga, 1998). This would suggest that English would be used less than it is.

During the 1990s, South Korea transformed itself from producing mainly low-value, labor-intensive goods to producing high-value, high-technology products that require significant marketing savvy and proficiency in terms of understanding the local consumers (Song, Montoya-Weiss, \& Schmidt, 1997). Many local consumers are motivated by the origin of the products (e.g., "Made in Korea"), which in turn may provoke negative attitudes toward both foreign advertisements and foreign products (Kwak, Jaju, \& Larsen, 2008). Such ethnocentricity (Shimp \& Sharma 1987) can extend beyond the product itself to the language used to convey the advertisement, especially if meaning is lost (Gerritsen, Korzilius, VanMeurs, \& Gijsbers, 2000). This combination of findings would suggest that marketing in Korea should take a highly localized approach, focusing on promoting the Korean language and culture. Yet, the preliminary work for this study of advertisements in Korean business, sports, economics, and fashion magazines found that over $90 \%$ featured English wording to some degree, even though over $75 \%$ of them were from Korean-based companies (Holmquist \& Park, 2010).

\subsection{Hypotheses}

One rationale for "connecting" to English associations (e.g., Korean fashion company Beanpole that uses an English name, English slogans, and Caucasian models for marketing) could be to avoid negative Korean association of lower production quality (Synovate, 2009). In fact, Korean consumers have the long tradition of regarding 'foreign products' as 'unconditionally good.' Historically, 'Made in USA' has served as an all-encompassing symbolism of superior quality. That perception distortion still lingers on, even in current times, and elicits unreasonable credibility issues with domestic products among Koreans (Kim, 2006). Furthermore, a basic popularity of American culture in South Korea (Pyong, 1989) and the high regard of Western products (Synovate, 2009) present themselves as one reason for Korean designers and manufactures to present themselves as Western. Previous research on the country of origin effect upon Korean consumers indicated that they placed greater value on the "Made in Korea" label over products manufactured in other Asian countries, with the possible exception of Japanese products. However, regarding American and European products, Koreans viewed them as more luxurious with higher value and quality than products made in Korea (Synovate, 2009). This provides an intriguing basis for further exploration of the increasingly prevalent use of English in Korean advertising. Therefore, quality perceptions may override the natural country-of-origin effects of Koreans. 


\section{Methodology}

\subsection{Research Design - Study One}

\subsubsection{Purpose and Scope}

This was an exploratory study of Korean advertisements. The purpose was to canvass various Korean media sources (e.g., newspapers, magazines, outdoor business signs and storefronts), to determine the percentage of promotions that exhibited English and how it was utilized (e.g., company name, brand name or catchphrase).

\subsubsection{Media Sources}

The following media sources were assessed for advertisements:

- The advertisements from 46 newspapers published over five weeks (twenty issues of the two national newspapers and one issue each of six separate local newspapers) were collected.

- The advertisements from 103 magazines published over a two year period (May 2007 - May 2009) were collected. The genres of these magazines included fashion, economics, business, automotive, and graphic design.

- The advertisements posted on 100 storefronts were photographed and analyzed in the downtown area of the city of Ulsan known as Samsan-dong, in South Korea.

\subsubsection{Procedure}

For the newspapers and magazines, all advertisements were tallied. The advertisements with English were highlighted and the totals were categorized based on the following functionalities: company name, product name, company logo, catchphrases, endorsement, action words, location, or event.

The assessments of the signs and storefronts were conducted on May 29, 2009 in Samsan-dong. This city center was chosen because it is not regarded as a tourist destination, and thus, any English wording found in advertisements was less likely to be a consequence of a local English-speaking presence. Furthermore, most cities geographically spanning South Korea from Seoul to Ulsan have multiple city centers that are similar in style and appearance to Samsan-dong. Therefore, the findings here should extrapolate to the other cities of South Korea; any advertising in English is thus intended for the sole purpose of the Korean populous in these areas. One hundred storefronts were randomly photographed with a digital camera. Afterwards, they were analyzed for the use of English in the company name, products, or services provided and for any catchphrases, phrases or other remarks using English.

\subsection{Study One-Results and Discussion}

A total of 46 newspapers containing 2044 advertisements were viewed. Amongst them, 1,235 (or 59.5\%) of these advertisements contained English words. Of the ads that used English:

- $\quad 40 \%$ had a company logo in English (e.g., the emblem for Ford motors, the logo for clothing designer DKNY)

- $20 \%$ used English to communicate the company name

- $7 \%$ used it to communicate a product name (e.g., iPod, Vitamin C)

- $17 \%$ used English in some form of catchphrase (e.g., "just do it", "quality choice", "good to the last drop")

- $7 \%$ gave an endorsement of their company or product in English (e.g., a statement issued by an athlete or medical doctor promoting the product or service)

- $4 \%$ used it to advertise a sale or event (e.g., "sale", "special")

- $1 \%$ stated a location in English (e.g., New York, L.A.) 


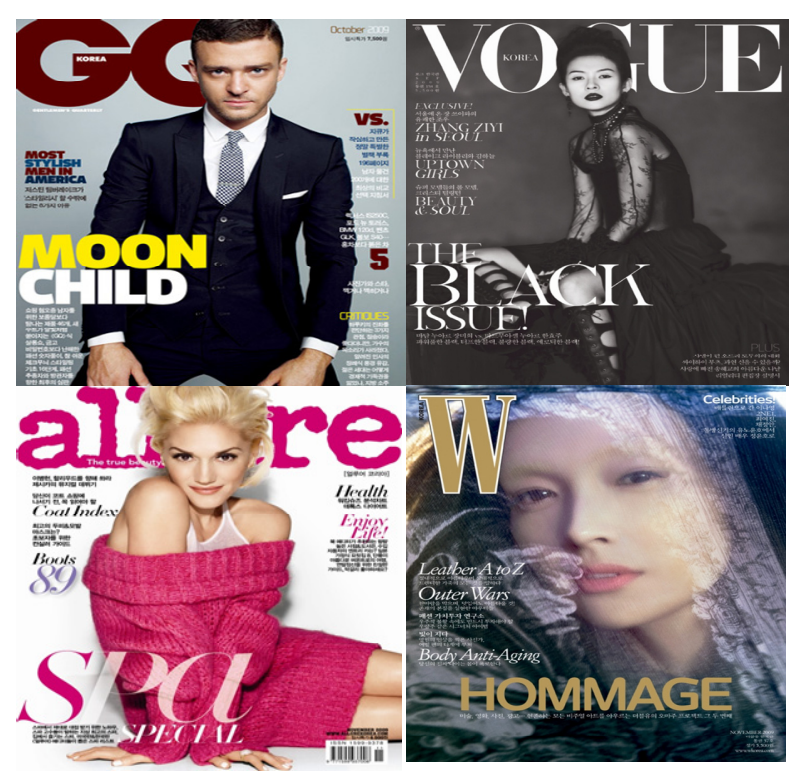

Figure1. Example of Korean magazine covers

Figure 1 has examples of the 103 magazines assessed. 6724 advertisements were found, with a total of 6102 (or 96\%) using English to some degree. Due to the large volume of magazines assessed, thirty magazines were randomly chosen and studied in detail. These thirty magazines contained 1753 advertisements, 1688 (96\%) of which used English. More specifically, English was used in the following contexts:

- $75 \%$ communicated the company name in English

- $41 \%$ communicated the product name

- $\quad 27 \%$ had a separate company logo written in English

- $18 \%$ used English in catchphrases

- $9 \%$ gave the endorsement of a star or another organization

- 7\% used English for action words (e.g., "climbing”, "running”)

- $2 \%$ gave a location

- $1 \%$ told of an event

Figure 2 has examples of the 100 storefront photographs analyzed, 71\% used English in some form. More specifically, English was used in the following manners:

- 39 of the 100 storefronts displayed their company name in English

- 25 wrote the primary products they carried in English

- 23 used English in a catchphrase of some kind

- 2 posted events (e.g., sales) in English 


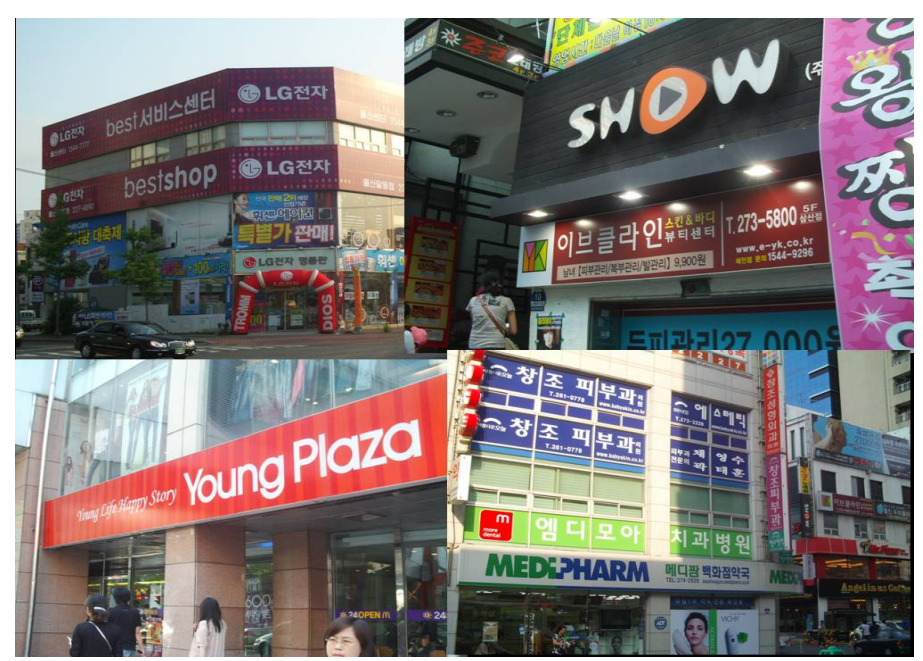

Figure 2. Example of Korean storefronts

Printing the company name or logo was the most popular use of English in print media. This was followed by the use of English in product names and the use of a catch phrase in print media. Additionally, of the 43 different magazines titles collected, only nine printed the name of the magazine in solely Korean; of the remainder, 21 had an English title written in a large type size accompanied by a small title in Korean, and the final 13 printed their title solely in English. This shows that the magazines themselves are using English as a marketing tool, not solely in advertisements, but in the branding of the products themselves.

In Korea, English is not solely being used by big business with large advertising campaigns, but also by small boutiques, salons, and family-run businesses. A possible explanation for this would be that these smaller shops are following the trend set by the large brand-name department stores and brand-name products that are flourishing, thereby mixing English into their storefront marketing. The most common form of English use was printing the store name in English.

It was also observed that English words such as menu, established, café, bar, or shop were frequently integrated into the storefronts. These were often descriptive words placed in a functional location, such as the English word menus the heading on a menu written otherwise entirely in Korean, which would not realistically be intended for use by a non-Korean speaker. This particular instance of use shows an integration of the English terms intended for the Korean consumer, not the English-speaking tourist (Study 3 also shows support for this). Again, this gives the local company the appearance of a Western company chain selling in Korea.

Select examples of Korean companies that use exclusively English store names on their storefronts include Prospec (shoes), K2 (mountain gear), Gear (hiking and mountain gear), Buy The Way (convenience store), Family Mart (convenience store), Lottaria (fast food), etc. Consequently, these stores blend into rows of Western stores such as Puma, Nike, Adidas, 7-Eleven, and McDonald's, appearing as other Western icons and bringing a sense of "luxury" to Korea. The apparent congruency provides a sense of harmony for the Korean consumer (Rokeach, 1968) allowing the Koreans store to "fit" into the international landscape. This fit is further bolstered by the early schema theories from Fredric Bartlett and of R.C. Anderson (Anderson, 1985) which would predict that through association, Koreans will connect Korean firms with these international firms over time. This can also be represented as a form of learning by association as described in associative learning theory (Skinner, 1938). Hence, if the consumer equates the look and style of the local brands with the international brands, they must be the same quality and value. This gives the local business a means to compete with the internationally branded stores by associating their look and style with these international brands.

These findings show that a majority of businesses are using English in Korean advertising (e.g., at least 60\%). In particular, the magazines and store fronts are exhibiting the most exposure of English. In fact, across all forms of media, the main use of English was to display the company logo or name followed by the use of a catchphrase. The next question we endeavored to explore was what form do these English descriptors take?

\subsubsection{Research Design - Study Two}

Purpose and Scope-This was an exploratory study focused on the most common English descriptive words utilized in Korean magazines found in study one. 


\subsubsection{Media Sources}

Given the high presence of English in Korean magazines we chose to focus on them alone for this study. These 30 magazines included a cross-section of fashion, automotive, sports, and economic magazines. The majority were fashion at $64 \%$ followed by $5 \%, 4 \%$, and $24 \%$ respectively (and $5 \%$ other).

\subsubsection{Procedure}

The 20 most commonly found English descriptive words were listed. This list was presented to participants in a survey, and participants were asked to provide their translations of the English words into Korean. The instructions were translated into Korean by a native Korean speaker. A Korean linguist with a Master's degree in English assessed the completed surveys and noted the number of English words that were translated correctly into Korean. The words to be translated were as follows:

NOUNS: Love; Beauty; Style; Velocity; Essence; Wonders

VERBS: Impress

ADJECTIVES: New; Advanced; Smart; Pure; Confident; Sensual; Casual; Chic; Heavy duty; Limited; Natural; Transforming; Premium

\subsubsection{Participants}

The 154 survey participants were students from the University of Ulsan in South Korea. Ages ranged from 18 to 49 (mean age group was $25-29$ ), $65 \%$ were male, $35 \%$ were female, and $96 \%$ were Korean, while $4 \%$ were from China. This population represents the consumers entering the market. Therefore, this sample was chosen.

\subsubsection{Study Two - Results and Discussion}

The 20 most commonly found English words presented in Korean magazines were only understood $58.5 \%$ of the time (see Table 1). This should be an interesting finding for Korean businesses that are depending on English words in terms of consumer comprehension. Arguably, the predominantly younger Koreans provide a conservative metric of this level of comprehension, given their exposure to English compared to their older counterparts. A use of a language does not always require comprehension. In the Western marketplace Asian characters are depicted on select products including clothing and tattoos. A market for these products exists, regardless of whether the Western consumer understands the true meaning of the characters or not ( $\mathrm{Li} \&$ Shooshtari, 2003). In the same manner, the Korean businesses may not be depending on comprehension, but rather on the belief that English maybe visually or phonetically more appealing to their cliental. Therefore English can be used as a persuasive influence within a promotional strategy.

This suggests further exploration is necessary to determine the intent of the Korean advertisers and their speculations as to the motives and needs of the Korean consumer. The next study explores the other side to this didactic relationship and tries to ascertain some of the views of the consumer and reveal their speculations as to why Korean businesses are utilizing English in their promotional strategies.

Table 1. Descriptive statistics of the vocabulary test

\begin{tabular}{ll}
\hline Participants: & 154 \\
Sex: & $64 \%$ male, $36 \%$ female \\
Average age group: & $26-29(50 \%$ of participants $)$ \\
Percentage Korean: & $95 \%(5 \%$ Chinese $)$ \\
Average education: & $3^{\text {rd }}$ or $4^{\text {th }}$ year college students $(51 \%)$ \\
Average work experience: & 0 to 1 years $(55 \%)$ \\
Average percentage correct on test: & $58.5 \%$ \\
\hline
\end{tabular}

\subsection{Research Design - Study Three}

\subsubsection{Purpose}

The purpose was to explore consumer perceptions of the rationale for using English in Korean advertising.

\subsubsection{Variables}

The survey was translated into Korean by a native Korean speaker. Four of the items measured in the level of agreement or disagreement ( 5 point Likert-type items strongly agree vs. strongly disagree) with the statements commonly proposed as rationale for English use. 
1) English is the international language.

2) Common phrases from the news and movies are easier to write and say in English.

3) Korea has many foreign visitors and tourists. Mixing English into Korean marketing is done for them.

4) English is the exotic language of the West and it is used as a marketing strategy.

5) Participants were asked to provide their single best response to the open-ended items. Two qualitative items were used:

6) Why do you think English is used in advertisements in Korea?

7) Why do you think English is used around the world in marketing?

Demographics included: Participant age, sex, native country, country of residence, level of education attained, and years of working experience.

\subsubsection{Participants}

The 192 participants of the survey were undergraduate students from the University of Ulsan in South Korea. Ages ranged from 18 to 55 (mean age category was 26-29), 54\% were male, 97\% were South Korean, and 3\% were Chinese.

\subsubsection{Procedure}

Four different undergraduate business classes were sampled. It was communicated that participation in the study was voluntary. Categorizing of the open ended questions was performed by the researcher and one translator. The responses were categorized based on the use of key words or phrasing the responses.

\subsection{Study Three - Results and Discussion}

The results of the survey are presented in Table 1. This table shows that the respondents believe that English is an international language and that it is primarily used in Korea as a marketing strategy. Study One revealed evidence of this in newspapers, magazines and storefront signage, yet it is still interesting to find that consumers also recognize its widespread use in Korean promotions. With $95.8 \%$ of the respondents agreeing that the use of English is international, it is not surprising that a majority of them also recognized the novelty or exoticness that makes it a mainstay marketing strategy even in countries like Korea with a strong country of origin effect. It was interesting to note, that the use of English may not necessarily be tied to it being easier to write and say certain words in English, though some believe it is (26.6\%). Nor was it just for tourists, suggesting it may be useful for attracting the attention of Koreans as well. The use of English in Korean advertising may indeed be a viable promotional strategy.

Table 2. Descriptive statistics for the attitude survey

\begin{tabular}{llll}
\hline Participants: & 192 & \\
Sex: & $54.5 \%$ male, $45.5 \%$ female & \\
Average age group: & $26-29$ years $(66.7 \%)$ \\
Percentage Korean: & $96 \%, 4 \%$ other $(3 \%$ Chinese, $1 \%$ Mongolian) \\
Average education: & $3^{\text {rd }}$ or $4^{\text {th }}$ year college students $(55.7 \%)$ \\
Average work experience: & 0 to 1 years $(77.6 \%)$ & \\
& Agree (1-2) & Neutral (3) & Disagree (4-5) \\
"English is international" & $95.8 \%$ & $4.2 \%$ & $0.00 \%$ \\
"English is easier" & $26.6 \%$ & $30.7 \%$ & $42.7 \%$ \\
"English is for tourists" & $32.3 \%$ & $36.5 \%$ & $24.5 \%$ \\
"English is an exotic marketing strategy" & $55.7 \%$ & $25 \%$ & $19.3 \%$ \\
\hline
\end{tabular}

"Why do you think English is used in advertisements in Korea?"

A total of 142 participants answered this qualitative question. The number one answer mentioned by $38.9 \%$ of the respondents referred to how it is perceived (e.g., luxurious, cool, sophisticated, trendy, stylish) (see Table 2). In fact, 7.8\% felt it was more eye-catching. This seems to indicate that the research by Synovate (2009) is correct in indicating that the Korean customers do view foreign products as more luxurious than domestic products. Furthermore, the notion that English looks more luxurious, more eye-catching, or stays in memory longeris supported by past research (see Song et al., 1997; Kwaket al., 2006). Therefore, this study indicates that using 
English in the Korean marketplace is an effective means to make products and services appear more desirable to the local consumer. Using English, therefore, is one possible strategy for increasing sales for international and domestic products.

With domestic companies competing with international companies, the use of English in their marketing strategy is becoming more common. Many Korean name brands such as "Polham", "Noton", "Beanpole", to name a few, are doing very well in the local marketplace, and are doing so with English marketing campaigns.

Table 3. English in Korea advertising

\begin{tabular}{lll}
\hline Why do you think English is used in advertisements in Korea? & $\begin{array}{l}\text { Total } \\
\text { respondents }\end{array}$ & \% respondents \\
\hline English looks more luxurious (e.g., cool, sophisticated, trendy, stylish) & 60 & 38.9 \\
English is the global language & 36 & 23.4 \\
Companies are trying to look more globalized (conveying globalization) & 23 & 14.9 \\
Part of a global marketing campaign & 16 & 10.4 \\
More eye-catching & 12 & 7.8 \\
Other (e.g., it is simple, natural, stays in memory longer, unique, more & 7 & 4.5 \\
expressive) & & \\
\hline
\end{tabular}

*Only the first responses are shown here.

The second most common explanation was that English is the "global language." Responses that inferred English as a common second language or used for international communication was categorized under "global language" (Riley, 2010). Responses that inferred the popularity English from international business influence or the use of English as a business language was categorized as "globalization." This is defined by Merriam-Webster (2013) as the development of an increasingly integrated global economy marked especially by free trade, free flow of capital, and the tapping of cheaper foreign labor markets. This implies some basic acceptance as English being the language of business, and that the Korean consumer is aware of international companies and global marketing campaigns (16\%). Therefore, one interpretation could be that Koreans understand that as a global language, English can be used to reach a large international audience. In turn this would explain their seeming willingness to use and respond to such marketing.

"Why do you think English is used around the world in marketing?"

Though similar to the previous qualitative question, this one focuses on a broader view of the acceptance of English in world business, not just in Korea. Of 140 respondents to this question, the predominant response (65\%) was "global language" (see Table 3). Here the participants seem to focus on the international functionality of English (perhaps as a common second language) over the luxury function of the language domestically in Korea. The second and third highest responses reveal the respondents' views of the role of the US and its direct association with English and infers the wider audience of English. The next two highest responses focus on the "look" of English and the inference that some words owe their origin to English, making translation difficult at times. This could infer that the respondents are not surprised by the use of English and their positive associations tell us its use by Korean businesses may be a viable Korean promotional strategy.

Table 4. English in world advertising

\begin{tabular}{lll}
\hline $\begin{array}{l}\text { Why do you think English is used around the world in } \\
\text { marketing? }\end{array}$ & $\begin{array}{l}\text { Total } \\
\text { respondents }\end{array}$ & \% respondents \\
\hline English is the global language & 91 & 65 \\
Influence and power of the United States & 22 & 15.7 \\
Used to reach a wider audience & 14 & 10 \\
Shows a "cool" or "modern look" for the advertising & 6 & 4.3 \\
Some ideas or topics are "hard to translate out of English" & 4 & 2.9 \\
Other(e.g., "don't know", "an aspect of value") & 3 & 2.1 \\
\hline
\end{tabular}

*Only the first responses are shown here. 
The results from Study Three show a large majority of consumers view the use of English in the Korean market as an effective means to catch the consumer's attention and show the product as an international competitive item.

\section{Limitations}

Study Two and Three respondents were not randomly selected. These were predominantly university students that arguably have more modern ideas about the role of English in Korean advertising than their older counterparts. Thus, our results can only be extrapolated to Korea's burgeoning consumers, as opposed to the general population. Further, these studies were exploratory and descriptive in nature; therefore no hypotheses could be tested. Instead interesting avenues of future research were revealed and so provided incremental contribution to a developing stream of international promotional literature.

\section{Conclusion}

Despite the large number of consumers worldwide becoming interested in the same products by means of mass communication such as the internet and television (Levitt, 1983; Ohiagu, 2010), there remain large differences between consumers from different countries (De Mooij, 2003). Regardless, it is interesting to note the reoccurring role of English as a communication tool that attempts to bridge these differences. Cultural awareness and reputation are major factors in the Korean market (Kraft \& Chung, 1992) and the current market has become one that requires savvy and proficiency on the part of the business in order to succeed (Song et al., 1997). Yet, there is a sense of irony, in that native Korean firms are having greater success over US firms in the Korean market and they are doing it by using marketing that integrates English as a means to show style and appeal to the Korean customers.

In addition, it is intriguing that few studies are exploring this promotional strategy, let alone the specifics of the functionality of English both from the perspective of the Korean firms that employ it and the Korean customers that receive it. Our three exploratory studies have provided some interesting insights and directions to this research and offered some propositions to guide future research.

\section{Acknowledgements}

We would like to thank the students of the College of Business at the University of Ulsan for their assistance in gathering newspapers and magazines. We would also like to give special acknowledgement to Park EunJu (박은주) and Kim SaRyang (김사량) for their assistance in data collection, and to Jeong HyoJeong (정효정) for the translation work for this research.

\section{References}

Anderson, J. R. (1985). Cognitive psychology and its implications (2nd ed.). New York: Freeman.

Cordell, V. (1992). Effects of consumer preferences for foreign sourced products. Journal of International Business Studies, 23(2), 251-269. http://dx.doi.org/10.1057/palgrave.jibs.8490267

Crystal, D. (1997). English as a global language. Cambridge, MA: Cambridge University Press.

Darling, J., \& Wood, V. (1990). A longitudinal study comparing perceptions of US and Japanese consumer products in a third neutral country: Finland 1975 to 1985. Journal of International Business Studies, 21(3), 427-450. http://dx.doi.org/10.1057/palgrave.jibs.8490827

De Mooij, M. (1994). Advertising Worldwide (2nd ed.). New York, NY: Prentice Hall.

Gerritsen, M., Korzilius, H., VanMeurs, F., \& Gijsbers, I. (2000). English in Dutch commercials: Not understood and not appreciated. Journal of Advertising Research, 40(6), 17-31.

Han, C. (1990). Testing the role of country image in consumer choice behaviour. European Journal of Marketing, 24(6), 24-40. http://dx.doi.org/10.1108/EUM0000000000609

Holmquist, J., \& Park, E. (2010). English in Korean magazines advertisements. Proceedings of the Orlando Conference of the International Journal of Arts and Sciences, March 1-4, Orlando, FL.

Kim, E. (2006). Overseas market in parallel with Korean market. Retrieved from http://www.gobizkorea.com/corp/success_view.jsp?id=56

Kraft, F., \& Chung, K. (1992). Korean importer perceptions of US and Japanese industrial goods exporters. International Marketing Review, 9(2), 45-59. http://dx.doi.org/10.1108/02651339210012456

Kwak, H., Jaju, A., \& Larsen, T. (2006). Consumer ethnocentrism offline and online: The mediating role of marketing efforts and personality traits in the United States, South Korea, and India. Journal of the 
Academy of Marketing Science, 34(3), 367-385. http://dx.doi.org/10.1177/0092070304270140

Levitt, T. (1983). The globalization of markets. Harvard Business Review, 2(11), 9-49.

Li, F., \& Shooshtari, N. (2003). Brand Naming in China: Sociolinguistic Implications. Multinational Business Review, 11(3), 3-18. http://dx.doi.org/10.1108/1525383X200300014

Lubatkin, M., Calori, R., Very, P., \& Veiga, J. (1998). Managing mergers across borders: A two nation test of nationally bound administrative heritage. Organization Science, 9(6), 670-684. http://dx.doi.org/10.1287/orsc.9.6.670

Merriam-Webster. (2013). Dictionary. Retrieved from http://www. Merriamwebster.com

Nicholls, J., \& Roslow, P. (1996). Main Message Retention: How Important is Language When Advertising to Hispanics. Marketing Research, 8(1), 39-45.

Ohiagu, O. (2010). Influence of information \& communication technologies on the Nigerian society and culture. In N. Ekeanyanwu \& C. Okeke (Eds.), Indigenoussocieties and cultural globalization in the 21st century. Germany: VDM Verlag Dr. Muller Aktiengesellschaft \& Co.

Parameswaran, R., \& Pisharodi, R. (1994). International Advertising. Journal of Advertising, 23(1), 43-56.

Pyong, P. (1989). Textbooks for Asian American studies. Amerasia Journal, 15(1), 259-266.

Riley, R. (2010). What is Global English? Retrieved from http://www.english.ucsb.edu/faculty/rraley/research/global-English.html

Rokeach, M. (1968). Beliefs, attitudes, and values. San Francisco: Jossey- Bass.

Schooler, R. (1965). Product Bias in Central American Common Market. Journal of Marketing Research, 2(4), 394-397. http://dx.doi.org/10.2307/3149486

Shimp, T., \& Sharma, S. (1987). Consumer Ethnocentrism: Construction and Validation of the CETSCALE. Journal of Marketing Research, 27(August), 280-289. http://dx.doi.org/10.2307/3151638

Skinner, B. (1938). The Behavior of Organisms. New York: Appleton-Century-Crofts. Sutton. RS, and AG Barto.

Song, X., Montoya-Weiss, M., \& Schmidt, J. (1997). The role of marketing in developing successful new products in South Korea and Taiwan. Journal of International Marketing, 5(3), 47-69.

Synovate. (2009). Consumers skeptical about quality of 'Made in China' labels. Retrieved from $\mathrm{http}: / /$ www.marketresearchworld.net/index.php?option=com_content\&task=view\&id=494\&Itemid=77

Tse, D., \& Gorn, G. (1993). An experiment on the salience of country-of-origin in the era of global brands. Journal of International Marketing, 1(1), 57-76.

Usunier, J. (2006). Relevance in Business Research: The Case of Country-of-Origin Research in Marketing. European Management Review, 3, 60-73. http://dx.doi.org/10.1057/palgrave.emr.1500049

Wang, L., \& Chen, F. (2004). Foreign languages used in Taiwan TV commercial ads: contents analysis. Proceedings of the BAI. International Workshop on Business Information, Amman, Jordan. 